\title{
Review \\ Evaluating the Effectiveness and Efficiency of Climate Information Communication in the African Agricultural Sector: A Systematic Analysis of Climate Services
}

\author{
Chidiebere Ofoegbu ${ }^{1, *}$ and Mark New ${ }^{2}$ \\ 1 Department of Forest Ecology and Management, Swedish University of Agricultural Sciences (SLU), \\ 90183 Umeå, Sweden \\ 2 African Climate and Development Initiative, University of Cape Town, Rondebosch 7700, South Africa; \\ Mark.New@uct.ac.za \\ * Correspondence: chidiebere.ofoegbu@slu.se; Tel.: +46-720227610
}

check for updates

Citation: Ofoegbu, C.; New, M.

Evaluating the Effectiveness and Efficiency of Climate Information Communication in the African Agricultural Sector: A Systematic Analysis of Climate Services. Agriculture 2022, 12, 160. https:// doi.org/10.3390/agriculture12020160

Academic Editors: Gniewko Niedbała and Sebastian Kujawa

Received: 22 November 2021

Accepted: 14 January 2022

Published: 24 January 2022

Publisher's Note: MDPI stays neutral with regard to jurisdictional claims in published maps and institutional affiliations.

Copyright: (c) 2022 by the authors. Licensee MDPI, Basel, Switzerland. This article is an open access article distributed under the terms and conditions of the Creative Commons Attribution (CC BY) license (https:// creativecommons.org/licenses/by/ $4.0 /)$.

\begin{abstract}
The use of climate services (CS) for the provisioning of climate information for informed decision-making on adaptation action has gained momentum. However, a comprehensive review of the literature to evaluate the lessons and experiences of CS implementation in the African agriculture sector is still lacking. Here, we present a systematic review (mapping) of 50 pieces of literature documenting lessons and experiences of CS adoption in the agriculture sector of 20 African countries. The qualitative analysis of the reviewed literature revealed: (1) CS implementation overwhelmingly relied on a participatory process through workshops and participatory scenario planning meetings to connect users with actors along the CS value chain of forecast production, translation, integration, and application. Additionally, innovations such as mobile phones and internet service are increasingly being integrated with CS to strengthen the relationship between CS providers and users. They are, however, mostly at the trial stage and tend to have a varying impact depending on available facilities and infrastructure in the community. (2) Although there is a growing recognition of the need for the integration of indigenous and scientific knowledge systems in the production of climate information, such integration is currently not happening. Rather, indigenous knowledge holders are engaged in a participatory process for insight on modalities of making scientific climate information locally relevant and acceptable. Given the aforementioned findings, we recommend further research on modalities for facilitating indigenous knowledge mainstreaming in climate information production, and investigation of options for using innovations (e.g., mobile) to enhance the interactions between CS users and CS providers. Such research will play a great role in scaling up the adoption of CS in the African agricultural sector.
\end{abstract}

Keywords: Africa; knowledge systems; climate change; agriculture; adaptation

\section{Introduction}

Agricultural development and sustainability in Africa are linked to the discourse around poverty and wellbeing [1,2]. Moreover, the agriculture sector in most developing countries is highly vulnerable to climate change due to compounding factors, including lack of capital, poor infrastructure, dependence on rain-fed agriculture, insecure land rights, and degradation of natural resources [3,4]. Consequently, several initiatives aimed at enhancing stakeholders' access to tailored and contextual climate information for adapting farming practices to climate and socioeconomic risks are being promoted [5-7]. In this regard, Climate Services (CS) has become a popular initiative. (In this study, we adopt the American Meteorological Society's definition of CS, which defines CS as scientifically-based information and products that enhance users' knowledge and understanding about the impacts of climate on their decisions and actions.) "Climate services, involve the timely 
production, translation, and delivery of useful climate data, information and knowledge for societal decision-making and climate-smart policy and planning" [8].

Several initiatives for scaling up the implementation of CS in the African agriculture sector have been adopted. Some of these initiatives include: the African Center of Meteorological Applications for Development (in 1995), the Climate Services Partnership (in 2011), the Global Framework of Climate Services (in 2012), and the Climate Services for Resilient Development Partnership (in 2017). These initiatives have been used in several approaches to facilitate the production and dissemination of climate information to stakeholders in the agricultural sector. The Global Framework of Climate Services, for example, implemented several projects in many African countries that aimed to facilitate timely delivery of contextual climate information to stakeholders through a collaborative participatory process [5,9-11]. Similarly, the African Centre of Meteorological Application for Development initiative implemented several projects aimed at producing forecasts of an appropriate timeline that are most suitable to decision-making in the agricultural sector [12-14].

Despite the growing number of initiatives promoting the adoption of CS in the African agricultural sector, there have been no regional level syntheses (Africa scale) of issues driving the adoption of CS and how CS has impacted adaptation actions in the African agricultural sector. Nevertheless, there have been several country-level studies on the contributions of CS to climate risk management in the agriculture sector [15,16]. Ref [17] investigated users' needs for CS. Ref [18] investigated the role of participatory processes in enhancing CS implementation in the agriculture sector. Ref [16] investigated the importance of CS for food security in East Africa. Ref [19] analyzed the process of forecast production and translation into relevant information for the agriculture sector. Ref [20] investigated the value of forecasts to farming activities, with the view of identifying content and timescale forecasts which are more appropriate for adapting farming operations to climate and socioeconomic risks.

Although these studies have provided important insight into the knowledge and experience of CS implementation in the African agriculture sector, they are, however, mostly at a national to sub-national scale. Thereby, they run the risk of missing important information for robust/generalizable interpretation of CS' impact on the African agriculture sector [21], which may lead to a biased interpretation of CS contributions to the African agriculture sector.

There is, therefore, a dearth of systematic review on the lessons and experiences of CS implementation in the African agriculture sector [22,23]. In order to fill this gap, we apply a systematic mapping review, drawing from lessons and experience in the literature on CS implementation across Africa. We ask: (1) how do the CS models characterize the process of climate information production and dissemination? (2) What types of information are provided by the CS? (3) How does CS facilitate indigenous knowledge systems' integration in the provisioning of these interventions? (4) How does the adoption of CS promote two-way learning (bottom-up and top-down) about climate-smart agricultural practices?

The rest of this paper is organized as follows: Section 2 describes the methods used for data extraction and analysis. Section 3 presents the results by (i) giving insights into how existing CS models shapes the process of climate information production and dissemination; (ii) elaborating on the characteristics of the CS and the types of information they disseminate; (iii) exploring how CS facilitates knowledge systems' integration; and (iv) providing insights on how the CS facilitates two-way learning about climate-smart agricultural practices. Section 4 concludes with a summary of the main findings and reflections on areas of future research.

\section{Methods}

\subsection{Systematic Mapping Review (SMR) Data Selection Process}

This paper adopts an SMR approach, wherein a thematic content analysis is used to analyze extracted data from all the reviewed literature. The execution of the SMR approach 
entailed six steps: definition of research questions, literature search, literature screening for papers, data extraction, coding, and mapping (Figure 1). A systematic literature search was conducted using the following databases: AGRIS, CAB Abstracts, ISI Web of Science, Scopus, Emerald, Open Access Theses and Dissertations (OATD), and Directory of Open Access Journals (DOAJ). We limited our selections to literature published between 2000 and 2019. We additionally searched for published reports, policy briefs, and working papers using the following databases and organization websites: Food and Agriculture Organisation of the UN (FAO), International Fund for Agricultural Development (IFAD), Centre for International Forestry Research (CIFOR), World Agroforestry Centre (ICRAF), Food and Agriculture Organization of the United Nations, International Food Policy Research Institute (IFPRI), International Institute for Environment and Development, International Centre for Tropical Agriculture (CIAT), Bioversity International, International Centre for Agricultural Research in the Dry Areas (ICARDA), International Crops Research Institute for the Semi-Arid Tropics (ICRISAT), International Institute of Tropical Agriculture (IITA), International Livestock Research Institute (ILRI), and World Agroforestry Centre.

The focus was on literature addressing the application of climate services in the agricultural sector in Africa. The study considered only studies published in English, which we acknowledge as a limitation. We used the following search terms [(Farm* OR Agr*) AND (Climate* OR Global change OR Resilience) AND (climate services OR climate info* OR knowledge systems OR knowledge network OR knowledge flow)] to search for literature. The literature search, including searches for published journal papers, reports, book chapters, conference papers, working papers, and policy briefs, resulted in 6713 papers.

The papers collated through the literature search were assessed for inclusion through a multi-tiered process: firstly based on the title, then by abstract, and finally by full-text review (Figure 1). The papers that were screened and included for full-text review must fulfill the following criteria: (1) Published between 2000 and 2019, (2) subject area must be related to CS use and management in the agricultural sector in Africa, (3) studies that addressed different models of CS used in the African agricultural sector and the knowledge systems that inform the functioning of the CS models were adjudged as meeting the relevant intervention criteria, and (4) studies that evaluated the impact and outcomes of CS on the sustainability of the African agricultural sector were judged as meeting the relevant outcomes criteria.

The screening for full-text review resulted in 50 published studies (Figure 1) which were subjected to the full-text review and used in the literature mapping analysis. Interestingly, the screening exercise resulted in the identification of 359 studies on CS use and management in the agricultural sectors of developing countries other than Africa. These 359 studies were not used in the literature mapping analysis but were reviewed to gain comparative insight into CS use and management in the agricultural sectors of other developing countries.

\subsection{Review Analysis}

The selected 50 pieces of literature (Table 1) focusing on Africa were analyzed using qualitative (thematic content) analysis with the view of generating all possible responses to the study's four research questions. The information extracted from the studies comprised households' / farmers' socioeconomic profile, conceptual framework, data collection methods, the process and type of information content produced and disseminated via the CS, and the dissemination pathways. The thematic content analysis was performed in Microsoft Excel to guide the thematic grouping of collected data and substantiate the interpretation of results. Repeated crosschecking during the data extraction and coding process served to reduce the risk of error.

Thematic content analysis was conducted by coding the extracted data into themes and categorizing the codes into broader themes. The coding was applied at three levels [24]: initial/open coding, focused coding, and thematic coding. The study's research questions 
guided the initial/open coding of the extracted data until no further new codes emerged (thematic saturation) [25]. Abductive reasoning was used to allow themes to emerge from the data to provide reasonable answers to all four research questions. In an abductive reasoning process, logical inferences are made by finding the simplest and most likely explanation to an observation or set of observations [26].

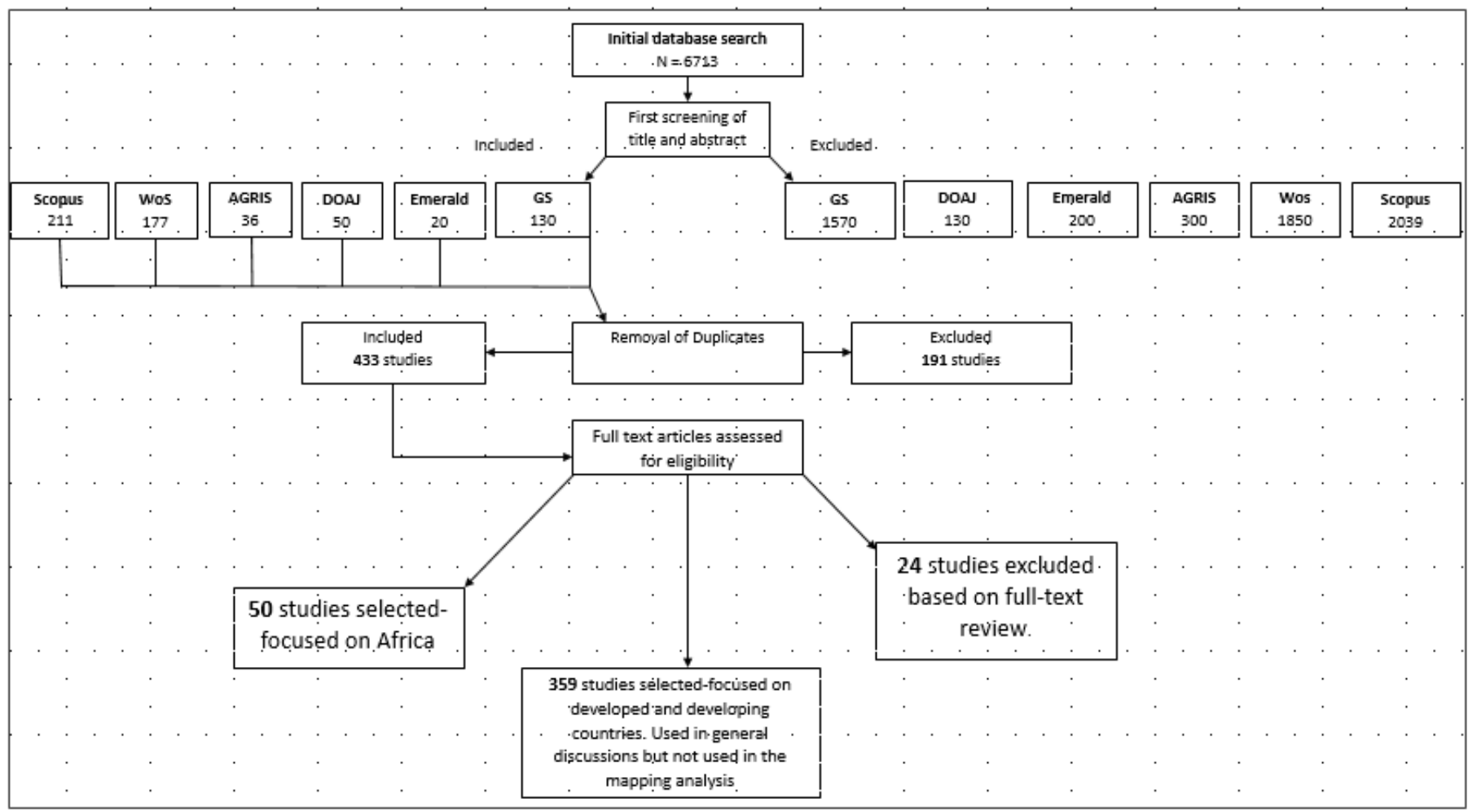

Figure 1. Summary diagram of the literature screening process.

\subsection{Overview of Extracted Data}

The unit of analysis (Table 1) in the selected studies is mostly sectoral targeting of the entire agricultural sector. Some of the studies are, however, more specific, targeting rural households, farmers, and/or pastoralists. The analysis method adopted in the selected studies varied. Most of the selected literature applied a mixed method, combining household surveys with focus group discussions (14). Some of the studies were based on the review and evaluation of implemented CS projects across Africa (9). The third most common methodological approach used in the selected studies is a model-based approach to improving the tailoring of climate forecasts to the farmers' contexts, and understanding the value of climate forecasts to crop and livestock productivity (4). Some of the studies are based on a traditional literature review to understand the conceptualization and application of CS (6). Some of the studies used a workshop approach to tease out factors shaping CS application and effectiveness (see Figure 2).

The distribution of the study site across regions in Africa varies, with most of the studies located in the Western Africa region (26\%). This is followed by the Southern African region (23\%). Twenty percent of the studies are located in the East Africa region. Although we did not record any study focusing specifically on the Central and Northern Africa region, $20 \%$ of the selected studies focused on Africa in general while the geographical region of $11 \%$ of the selected remains unspecified. 


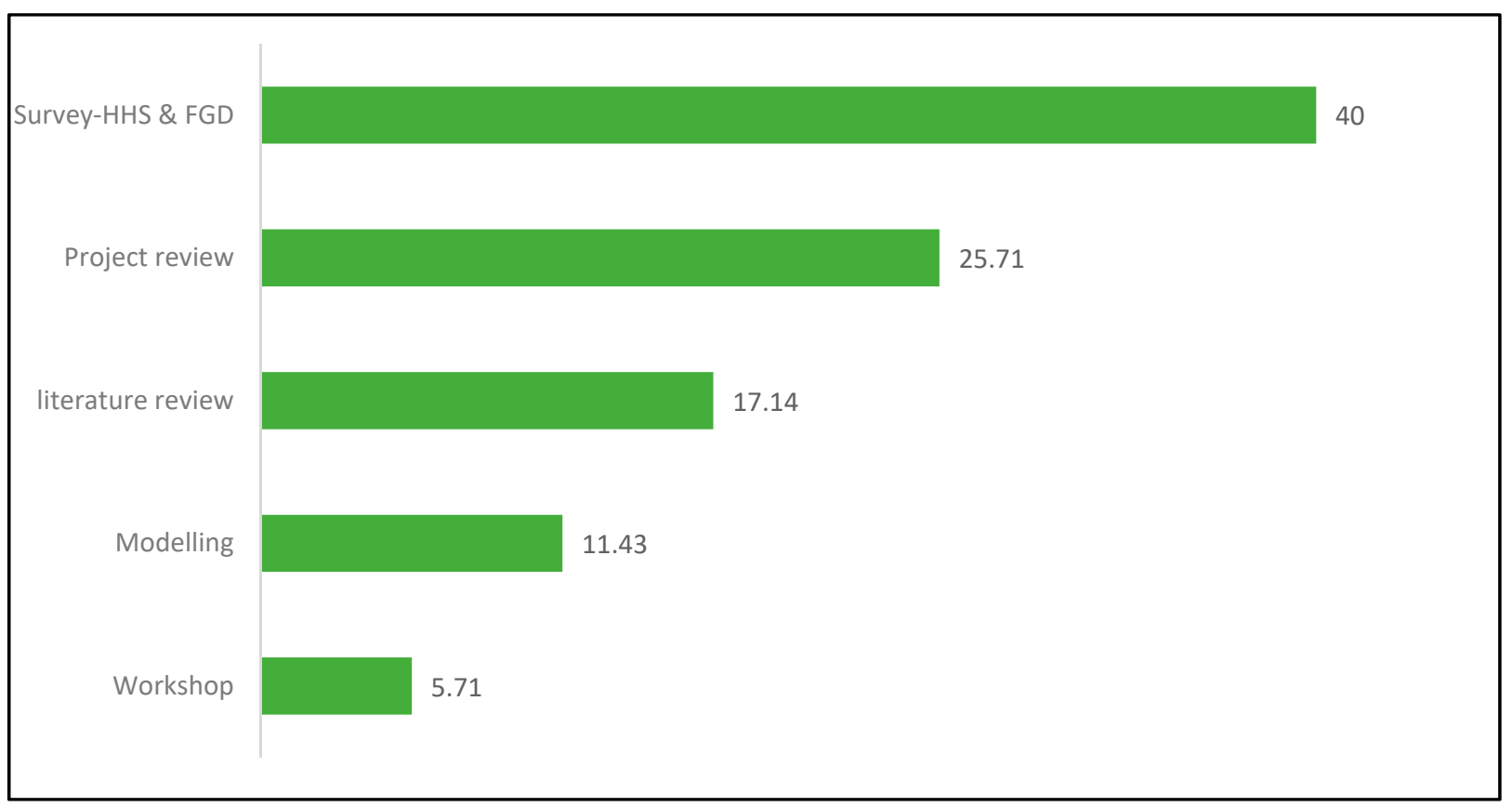

Figure 2. Methodological approach usage in CS project analysis (\%).

Table 1. List of the 50 kinds of literature analyzed for this study.

\begin{tabular}{|c|c|c|c|c|}
\hline SN & Publication Type & Unit of Analysis & Study Scale & Study Country \\
\hline 1 & Research article & Farmers & National & Senegal \\
\hline 2 & Research article & Agriculture sector & National & Kenya \\
\hline 3 & Research article & Agriculture sector & Regional-Southern Africa & Swaziland, Zambia \\
\hline 4 & Research article & Farmers & National & Burkina Faso \\
\hline 5 & Research article & Agricultural institutions & National & Burkina Faso \\
\hline 6 & Research article & Households & National & Kenya \\
\hline 7 & Research article & Sectoral-Agriculture & National & Kenya \\
\hline 8 & Research article & Sectoral-Agriculture & Regional-West Africa & Mauritania, Niger, Ivory Coast, and Ghana \\
\hline 9 & Research article & Sectoral-Agriculture & Regional-East Africa & Kenya and Ethiopia \\
\hline 10 & Research article & Farmers & Regional & Ghana, Uganda and Cameroon \\
\hline 11 & Research article & Farmers & Regional-East Africa & Kenya, Ethiopia, IGAD countries \\
\hline 12 & Research article & Households & National & South Africa \\
\hline 13 & Research article & Farmers & National & Zimbabwe \\
\hline 14 & Research article & Farmers & National & Lesotho \\
\hline 15 & Research article & Households & National & Lesotho \\
\hline 16 & Research article & Households & Sub-national & Mali \\
\hline 17 & Research article & Sectoral-Agriculture & Global, but have Kenya case studies & Global \\
\hline 18 & Research article & Sectoral-Agriculture & Regional-Africa & NA \\
\hline 19 & Research article & Sectoral-Agriculture & National & Malawi \\
\hline 20 & Research article & Sectoral-Agriculture & Regional-Africa & NA \\
\hline
\end{tabular}


Table 1. Cont.

\begin{tabular}{|c|c|c|c|c|}
\hline SN & Publication Type & Unit of Analysis & Study Scale & Study Country \\
\hline 21 & Research article & Farmers & National & Zimbabwe \\
\hline 22 & Research article & Sectoral-Agriculture & Regional-Africa & Africa \\
\hline 23 & Research article & Sectoral-Agriculture & global & Global \\
\hline 24 & Research article & Pastoralists & Regional & Kenya, Ethiopia \\
\hline 25 & Research article & Households & National & Uganda \\
\hline 26 & Research article & Pastoralists & National & Burkina Faso \\
\hline 27 & Research article & Pastoralists & National & Burkina Faso \\
\hline 28 & Research article & Sectoral-Agriculture & West Africa & West Africa countries \\
\hline 29 & Research article & Households & National & Burkina Faso \\
\hline 30 & Research article & Farmers & National & Senegal \\
\hline 31 & Research article & Sectoral-Agriculture & National & Uganda \\
\hline 32 & Research article & Sectoral-Agriculture & National & Ghana \\
\hline 33 & Research article & Pastoralists & National & Senegal \\
\hline 34 & Research article & Households & National & Zambia \\
\hline 35 & Research article & Sectoral-Agriculture, water & Global & Africa \\
\hline 36 & Research article & Households & National & Uganda \\
\hline 37 & Research article & Farmers & National & Mali \\
\hline 38 & Technical report & Sectoral-Agriculture & Regional-Africa & Africa \\
\hline 39 & Book chapter & Households & National & Uganda \\
\hline 40 & Book chapter & Households & National & Uganda \\
\hline 41 & Review paper & Sectoral-Agriculture & Regional-Sub-Saharan Africa & Africa \\
\hline 42 & Review paper & Sectoral-Agriculture & Global & Africa-South Africa, Zimbabwe \\
\hline 43 & Review paper & Sectoral-Agriculture & Global & Africa \\
\hline 44 & Review paper & Sectoral-Agriculture & Global & Sudan, Kenya \\
\hline 45 & Review paper & Sectoral-Agriculture & Global & unspecified \\
\hline 46 & Review paper & Sectoral-Agriculture & Regional & West Africa countries \\
\hline 47 & Review paper & Sectoral-Agriculture & Global & NA \\
\hline 48 & $\begin{array}{l}\text { Conference } \\
\text { proceedings }\end{array}$ & Sectoral-Agriculture & Sub-national & Kenya \\
\hline 49 & Working paper & Households & Regional & Africa \\
\hline 50 & Working paper & Farmers and pastoralists & National & Tanzania \\
\hline
\end{tabular}

\section{Results}

\subsection{Characterizing the Process of Climate Information Production}

The organizational collaboration process underpinning the process of climate information production and dissemination in all the reviewed case studies followed a similar value chain approach. The value chain has three distinct phases: forecast production, forecast translation and integration into agriculture relevant climate information, and climate information communication and adoption in decision-making [5,9,11,27-29]. The nature of the relationship among the actors along the three phases of the value chain is the key factor that shapes the nature and function of the CS model in the African agriculture sector. Figure 3 presents the identified key challenges associated with each of the three phases of the CS value chain. 


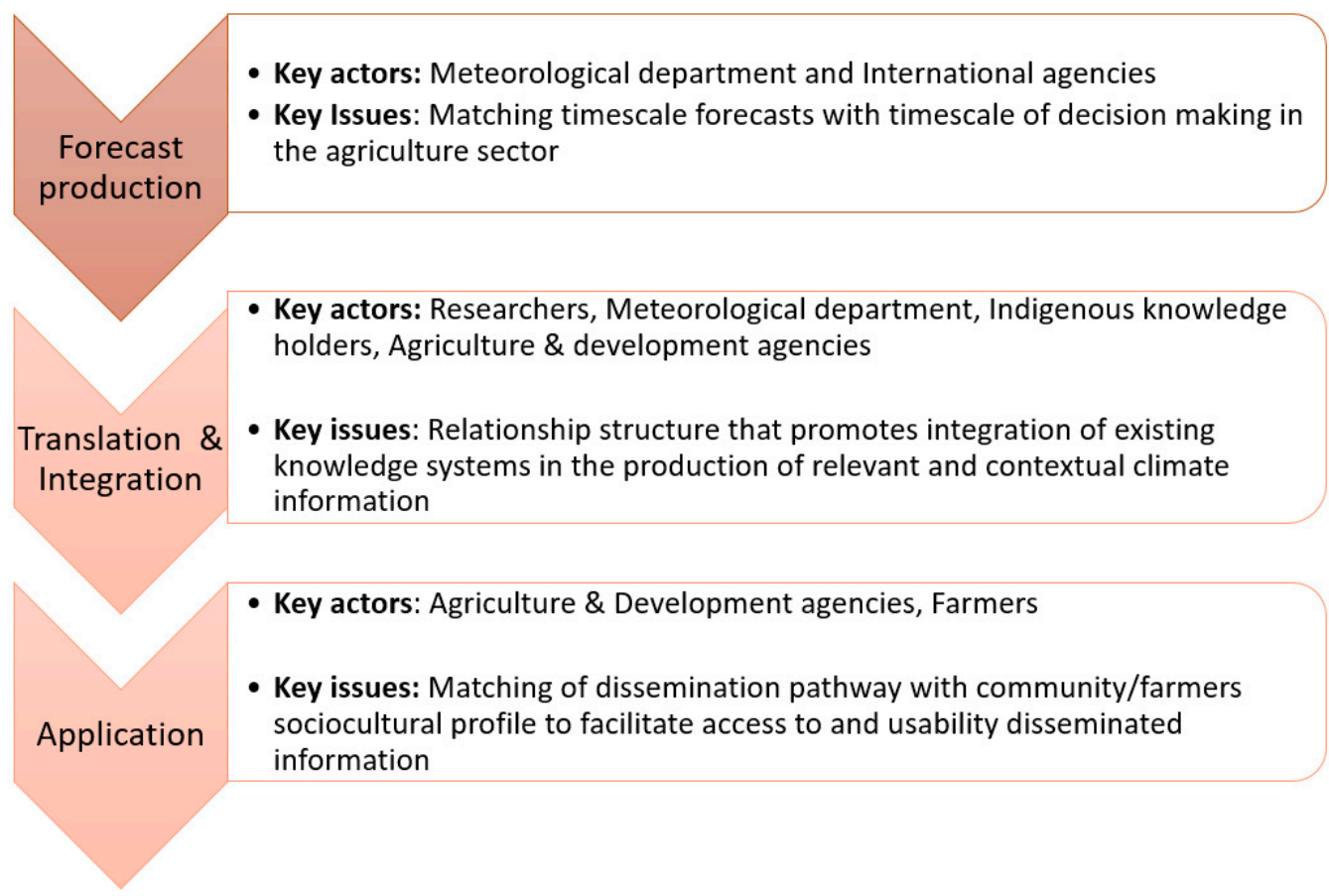

Figure 3. CS value chain characterizing phases of forecast production and translation climate information.

Forecast Production: Most activity at the forecast production stage focuses on the production of forecasts that are in accord with the timescale at which decisions are made in the agriculture sector [30-32]. The assumption is that such harmony can increase the relevance and adoption of forecasts in the agriculture sector. This is further discussed in Section 3.2. The key actors are the national meteorological departments and regional/international forecast-producing organizations.

Translation and Integration: The translation and integration stage focuses on the application of a transdisciplinary approach through the encouragement of a collaborative process that facilitates interaction among diverse actors of the varying disciplinary fields to promote the translation and integration of forecasts into information on climate risk warning and risk response strategy relevant for the agriculture sector $[13,15,33-35]$. The key issue includes the establishment of an appropriate modality for the integration of scientific and indigenous knowledge systems in produced climate information to facilitate its sociocultural relevance and acceptance. This is elaborated in Sections 3.2 and 3.3

Application: The application stage focuses on a two-way interaction with farmers to understand their socio-cultural characteristics to implement a dissemination pathway that will facilitate access and uptake of disseminated information [36-40]. The key issue identified in this phase includes the development of a comprehensive socioeconomic profile of the community to implement an appropriate dissemination pathway that facilitates rural people's access to disseminated information while also providing them with a platform for feedback on their experience and expectation for revision and reformation of disseminated information. This issue is elaborated in Sections 3.3 and 3.4

\subsection{Types of Interventions and Climate Information Provided through CS}

The types of interventions provided in the African agriculture sector through CS were thematically grouped into 11 categories (Figure 4). Most of the interventions are within the thematic group of analysis of adoption pathways (19\%). The type of interventions within this group mostly focussed on analyzing the adoption pathways for effective CS uptake in the agriculture sector $[9,40,41]$. To optimize CS adoption by relevant actors' across scales in the African agriculture sector, project implementers employ several strategies including socioeconomic characterization of households to identify efficient and effective information 
dissemination pathways $[9,11,42,43]$, while some projects used peer-to-peer and social learning to promote and facilitate CS use awareness among potential users [42,44]. Some projects chose an economic pathway by analyzing households willingness to pay for

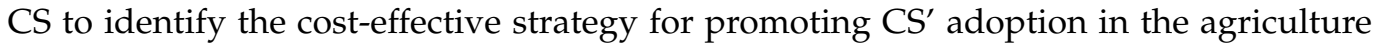
sector $[45,46]$.

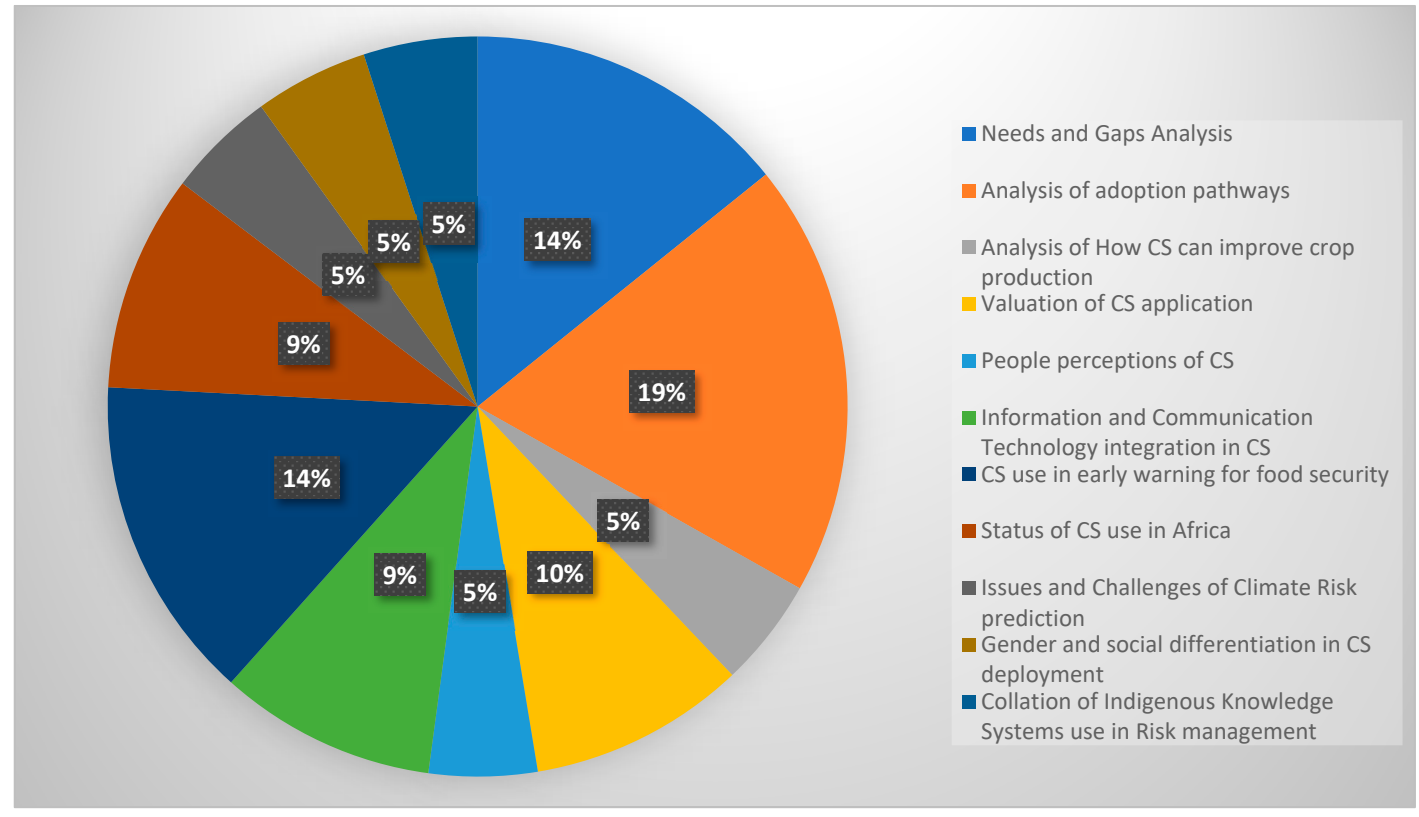

Figure 4. Thematic groupings of CS according to issues of focus.

The second most common thematic groups of interventions are needs and gaps analysis (14\%) and early warnings for food security (14\%). In the context of needs and gaps analysis, CS is used to specifically target the local contextual needs of farmers/users concerning their information needs for livelihood system adaptation to climate change. In the context of early warning, CS is used for timely and relevant information communication to users to facilitate their early preparation for various risks including drought, wildfire, erratic rainfall, etc., to help ensure food security at household and community levels. The third most common thematic group of intervention is the valuation of CS' application in the agriculture sector $(10 \%)$. Interventions within this thematic group are mostly focused on the evaluation of CS' contribution to the economic viability of agricultural practices and CS' contribution to agriculture productivity, e.g., crop yield. The fourth most common thematic group of interventions are Information and Communication Technology (ICT) integration in CS (9\%) and status of CS use in Africa (9\%). Interventions focusing on ICT integration mostly focused on the investigation of options for using ICT to enhance farmers' access to relevant climate information in a cost-effective and timely manner. These types of studies are relatively recent but are growing exponentially in number. A positive trend was observed between the year of project implementation and the type of intervention the projects provide. This is especially true for project interventions focused on ICT integration in CS applications. Although this type of intervention is currently the least common, nevertheless, most of the projects providing this type of intervention are recent, with most occurring between 2011 to 2019. This is a strong indication that this type of intervention is steadily growing and may become the dominant type of intervention in the future. Other thematic groups of interventions that are sparingly provided through CS include: analysis of how CS can improve crop production (5\%), people's perceptions of CS $(5 \%)$, issues and challenges of climate risk prediction (5\%), gender and social differentiation in CS deployment (5\%), and collation of indigenous knowledge systems use in risk management (5\%). 


\subsection{Types of Climate Information Provided through CS}

There are three main types of climate information commonly provided through CS. These are forecasts, agrometeorological services, and early warnings.

Forecasts use in farming operations: Several CS projects in the African agriculture sector have applied forecasts of varying timescale in providing risk warning and risk response advisory services to farmers $[36,47,48]$. The literature synthesis and mapping process identified five timescale forecasts as the most widely used forecasts in the production of climate risk warnings and risk response advisory services: (1) Weather forecasts (daily to weekly), (2) Seasonal forecasts (on a timescale of 1-6 months), (3) Short-term forecasts (1-5 years), (4) Intra-decadal/Medium-term forecasts (5-10 years), and (5) Decadal forecasts. The most commonly used among these forecasts are short-term, seasonal, and weather forecasts $[11,28,33]$. Intra-decadal and decadal forecasts are sparingly used in agricultural risk management, even though they may be more useful for making a strategic decision and anticipatory adaptation plans $[26,27,38]$.

Table 2 presents a summary of how these forecasts are used in risk warning and risk response advisory services for informing stakeholders in the agriculture sector. We also present additional information on how the forecasts are used in decision making and the identified gaps based on users' information needs and the type of information communicated to them [49].

Table 2. Observed forecasts and their use in the agriculture sector.

\begin{tabular}{|c|c|c|c|c|}
\hline Forecast & Typical Content & $\begin{array}{c}\text { Application in Decision } \\
\text { Making }\end{array}$ & Gaps & Reference \\
\hline $\begin{array}{l}\text { Weather forecasts } \\
\text { (daily to weekly) }\end{array}$ & $\begin{array}{l}\text { They normally contain } \\
\text { detailed likelihood of the } \\
\text { occurrence of climate } \\
\text { events, e.g., rainfall } \\
\text { possibility }\end{array}$ & $\begin{array}{l}\text { Decision making on daily } \\
\text { farming operations: } \\
\text { Timing of fertilizer and } \\
\text { chemical applications, } \\
\text { timing of fungicide } \\
\text { applications. }\end{array}$ & None identified & {$[10,27,50]$} \\
\hline $\begin{array}{l}\text { Seasonal forecasts (on } \\
\text { a timescale of } \\
1-6 \text { months) }\end{array}$ & $\begin{array}{l}\text { Seasonal rainfall onset and } \\
\text { cessation, the rainfall } \\
\text { amounts, rainfall duration, } \\
\text { rainfall distribution, and } \\
\text { anticipated extreme } \\
\text { weather events such as } \\
\text { drought, flood, fire risk, } \\
\text { strong wind/wind gusts, } \\
\text { hail, frost, among others. }\end{array}$ & $\begin{array}{l}\text { Used in making tactical } \\
\text { decisions on the } \\
\text { scheduling of: When to } \\
\text { plow the fields, when to } \\
\text { sow, when to add } \\
\text { fertilizers, when to } \\
\text { irrigate, when to provide } \\
\text { pesticides, when to } \\
\text { harvest, when to sell, and } \\
\text { choice of seed variety } \\
\text { for planting. }\end{array}$ & $\begin{array}{l}\text { Desired but not widely } \\
\text { available information include } \\
\text { optimal sowing date, } \\
\text { evapotranspiration, insolation, } \\
\text { soil water availability (to } \\
\text { inform the scheduling } \\
\text { of irrigation). }\end{array}$ & {$[10,13,31,36,45,48]$} \\
\hline $\begin{array}{l}\text { Short-term forecasts } \\
\text { (1-5 years) }\end{array}$ & & $\begin{array}{l}\text { Mostly used in the } \\
\text { livestock sector for } \\
\text { preparedness messages } \\
\text { and education on: } \\
\text { fodder availability, water } \\
\text { resource availability, } \\
\text { potential disease } \\
\text { occurrence zone. }\end{array}$ & $\begin{array}{l}\text { Desired but not yet widely } \\
\text { available information includes: } \\
\text { Forecasts of parasite and } \\
\text { animal diseases }\end{array}$ & {$[13,31,36,41,45,46,48]$} \\
\hline $\begin{array}{c}\text { Intra-decadal/ } \\
\text { Medium-term } \\
\text { forecasts (5-10 years) }\end{array}$ & Sectoral decision making & & & {$[10,13,46]$} \\
\hline Decadal forecasts & & & $\begin{array}{l}\text { No record of the use of decadal } \\
\text { to medium-term projections. } \\
\text { Although it acknowledged } \\
\text { that such could inform future } \\
\text { agricultural research } \\
\text { investments, irrigation and } \\
\text { water resource management } \\
\text { planning, and training needs } \\
\text { for agricultural extension staff. }\end{array}$ & {$[46,51]$} \\
\hline
\end{tabular}


The generation of timescale forecasts that are relevant to the timeline at which decisions are made in the agriculture sector is increasingly relying on the nature of the partnership and collaboration among the transdisciplinary actors (climatologists, meteorologists, and agriculturalists) operating in the agriculture and climate information space. Although this partnership has played a key role in advancing the uptake of CS in the Africa agriculture sector, there are, however, gaps reported in the selected studies concerning differences between the type of information desired by users and the type of information they receive via the CS.

Most of the reported gaps are associated with seasonal forecast usage. This includes several additional important pieces of information to optimize the resilience of agricultural operations to climate change's impact. An example is a desire for information on crop water requirements and evapotranspiration rate, which users believe will enhance the efficiency of the use of irrigation systems as a climate change response strategy $[4,50]$. There were also identified gaps in the literature that are associated with the use of short-term forecasts. Many studies reported the absence of forecasts on the precise occurrence of parasite and/or livestock disease as a result of climate change. Users believe that such information will enable them to anticipate and adjust their management strategy to manage climate change's impact on their livestock $[5,52]$. There are, however, differences in the extent to which seasonal and short-term forecasts are used across African countries. For example, a study in Malawi reported that there is no availability of models to predict the different periods when the rains can set in $[34,35]$, whereas this type of limitation is not an issue in many other African countries [9]. In general, we did not record any gap associated with the use of intra-decadal and decadal forecasts in the agriculture sector; this is largely because such forecasts are currently seldom used in the African agriculture sector.

Agrometeorological services: Agrometeorological services are the second most common type of climate information provided by the CS [36,53]. Included in this category is information provided to manage the impact of both climate change and climate variability. This includes advisory information on the scheduling of planting operations, weeding, fertilizer applications, etc. CS is also, in some cases, used to provide information on climatesmart agriculture practices (CSA). The type of CSA information communicated includes conservation farming practices like ridging, minimum tillage, soil conservation practices, etc. [52,54]. The use of CS to communicate agrometeorological services and CSA to farmers is acknowledged as a valuable innovation to assist decision-making and develop farmers ${ }^{\prime}$ specific adaptive capacities [36]. Table 3 presents a summary of how agrometeorological services are used in farming operations and the associated benefits. The benefits associated with agrometeorological services integration in farming operation decision-making can be summarized by an increase in crop productivity and a decrease in cropping costs in terms of inputs and working time [36,37].

Table 3. Commonly used agrometeorological services.

\begin{tabular}{|c|c|c|c|c|}
\hline Farming Operation & Agro-Meteorological Services & CSA & Benefits & References \\
\hline Land preparation & $\begin{array}{l}\text { Advice on weather and seasonal } \\
\text { forecasts, and crop calendar }\end{array}$ & $\begin{array}{l}\text { Land conservation } \\
\text { practices }\end{array}$ & & {$[36,55]$} \\
\hline Weeding & $\begin{array}{l}\text { Soil moisture and } \\
\text { weather forecasts }\end{array}$ & $\begin{array}{l}\text { Land conservation } \\
\text { practices to reduce weed } \\
\text { infestation }\end{array}$ & & {$[52,54]$} \\
\hline Sowing & $\begin{array}{l}\text { Forecasts on onset and offset of } \\
\text { rain seasons with } \\
\text { sowing calendar }\end{array}$ & & $\begin{array}{l}\text { Avoid loss due to crop failure } \\
\text { to germinate or establish } \\
\text { because of dry spells }\end{array}$ & {$[44,52,56]$} \\
\hline Crop variety choice & $\begin{array}{l}\text { Insight from forecasts on rain } \\
\text { distribution, average annual } \\
\text { rainfall, and seasonal forecasts in } \\
\text { combination with crop calendar } \\
\text { is used to advise farmers on crop } \\
\text { type and variety to sow }\end{array}$ & & & {$[45,52]$} \\
\hline
\end{tabular}


Early warning interventions: The third type of climate information provided through CS are early warnings. Early warning intervention provisioning is commonly used for drought, flood, and wildfire risk warnings [27,40,44,52,54]. Early warnings are rarely solely disseminated to users; rather, they are provided in combination with agrometeorological services $[33,36,37,45]$. The early and timely delivery of early warnings is increasingly being facilitated through the integration of ICT CS dissemination strategy.

\subsection{Extent of Scientific and Indigenous Knowledge Systems Integration in CS}

The review of studies to understand the extent to which scientific and indigenous knowledge systems are integrated into CS revealed that knowledge system integration is not yet an issue of significant emphasis in CS adoption in the African agriculture sector. Of the reviewed studies, $72 \%$ applied only scientific knowledge systems and did not in any way integrate indigenous knowledge system CS applications [9-11,41]. However, 17\% of the reviewed studies collated indigenous practices of climate risk prediction and risk response strategy $[8,13,56]$. Although the documented indigenous knowledge system is not included in the content of information disseminated via the CS, they are nevertheless, on rare cases, used to fine-tune the statistical forecast of risks and risk response strategy [55,57].

Nonetheless, indigenous knowledge systems are not entirely neglected in the current model of CS deployment. Eleven percent of the reviewed literature reported the inclusion of indigenous knowledge holders in the process of a forecast's translation into relevant climate information for actors in the agriculture sector. The study deduces that the inclusion of indigenous knowledge holders in the process of CS deployment is mainly for two purposes. The first is to promote the acceptance of CS by rural farmers, because rural farmers in Africa overwhelmingly rely on indigenous knowledge systems for their operations [27,41,55]. The second purpose is for the fine-tuning of statistical forecasts to suit the local context of climate risk warning and risk response strategy.

Resistance to information adoption often occurs when new knowledge interplays negatively with old knowledge $[30,57,58]$. This assertion can be attributed to the challenge of meteorological forecasts' acceptance, especially by rural farmers in many African countries where CS is sometimes rejected in favor of the old way of farming because the new information tends to interfere with the traditional way of farming [55]. This type of resistance is very common among the elderly, who tend to favor the traditional way of farming that is rooted in their indigenous knowledge system [59]. However, there is a growing trend towards the co-production of forecasts, whereby indigenous knowledge holders collaborate with researchers and meteorologists to generate plausible forecasts for their locality $[8,27,49]$. The approach currently tends to focus on using a participatory process for consensus on plausible risk scenarios for the local community as a way of securing the people's trust and confidence in the disseminated information $[27,35]$. As a result, most CS lack information on the indigenous system of risk prediction and risk response.

The study, therefore, infers that an actionable point of entry for indigenous knowledge system integration into CS would be to integrate scientific risk response strategy with local sociocultural farming coping practices. Integration must occur across all three phases of the CS value chain. This means much needs to be done to encourage integration at forecasts production and forecast translation phase.

\subsection{CS' Role in Facilitating Two-Way Learning for Robust Adaptation Action}

To analyze how the adoption of CS has facilitated two-way learning (bottom-up and top-down) about climate change mitigation and adaptation in the agriculture sector, we analyzed the selected literature for information on methods used to facilitate a feedback relationship among actors in the value chain of CS. This is because the production and dissemination of contextual climate information for actors in the agriculture sector relies mainly on the structure and feedback loop of the network of relations that exists among the actors $[7,16]$. 
The analysis of the selected literature indicates that the relationships among the actors in the CS value chain operate mainly on a participatory collaborative process. This collaborative process is primarily through workshops and participatory scenario planning meetings. The participatory collaborative process is used for the production of relevant climate information, development of appropriate channels for information dissemination, and promotion of local ownership in climate information production and dissemination $[9,49,60]$. This ultimately influences learning and revisiting to ensure the relevancy, suitability, and usability of information disseminated via the CS [35,61,62]. Table 4 provides a summary of recorded evidence of how the participatory process approach in CS deployment facilitates two-way learning (bottom-up and top-down).

Table 4. Evidence of participatory process influence in CS application.

\begin{tabular}{ccc}
\hline Case & Key Impact & Reference \\
\hline $\begin{array}{c}\text { The participatory process is targeted at facilitating the relationship between CS } \\
\text { providers and local farmers to enable CS providers to understand the user's } \\
\text { socio-cultural context to provide contextual information }\end{array}$ & User's context \\
$\begin{array}{c}\text { The participatory process was used to spur farmers group interest in CS which } \\
\text { resulted in them taking ownership and initiative of the process of CS } \\
\text { dissemination and application in farming practices in their locality }\end{array}$ & Ownership and taking the initiative \\
\hline $\begin{array}{c}\text { The participatory process was used to improve local people understanding of } \\
\text { and trust meteorological weather and climate forecasts }\end{array}$ & $\begin{array}{c}\text { Trust and confidence in } \\
\text { meteorological forecasts }\end{array}$ \\
\hline $\begin{array}{c}\text { There are several recorded case studies where participatory processes have } \\
\text { successfully been used to improve the rate of CS application in farming } \\
\text { practices by local farmers }\end{array}$ & CS usage \\
\hline $\begin{array}{c}\text { There are several recorded case studies where participatory processes have } \\
\text { successfully been used to provide inclusive training to users to enhance their } \\
\text { capacity to understand and apply disseminated information via the CS }\end{array}$ & Capacitation of users \\
\hline
\end{tabular}

Nevertheless, the cost and difficulty of gathering all relevant stakeholders in a workshop are limiting the effectiveness of this approach. This is evident in the reported gaps (Table 2) in the information disseminated through the CS [32,40]. CS providers, therefore, need to be proactive in interacting with the farmers regarding their needs for climate information and in determining a more suitable feedback mechanism for maintaining the relevancy of CS $[63,64]$. To this end, several methods for reaching smallholder farmers have been attempted by various agencies, but a scalable solution has yet to be found [16,31]. The internet and mobile phone (SMS) are the two prominent new and innovative methods being used to facilitate collaborations among the actors. They are, however, still in infancy and need a lot of research to improve their efficiency. The use of the internet, for example, has been constrained by lack of facilities and, in some cases, by unwillingness on the part of the local people to pay the internet fee for accessing CS [44,65]. SMS, on the other hand, has also been constrained by poor signal/reception in many regions and, in most cases, the feedback communication between CS providers and users via SMS has been reported to be inefficient and inadequate [66]. There is, therefore, a need for further investigation for insight on appropriate modalities for facilitating impactful and sustainable reciprocated relationships among the actors along the CS value chain via the use of SMS and the internet, particularly within the context of African rural communities.

\section{Conclusions}

The integration of CS in climate information in the decision-making process in the agriculture sector is a valuable innovation that can enhance the resilience of the sector to the impacts of climate change. In the reviewed literature on selected African countries agricultural sectors, considerable progress has been made in the integration of CS in the decision-making process. The outcomes of the analysis of the study's four research questions are summarized as follows: 
The role of CS in climate information integration in decision-making in the agricultural sector is explained through the three distinct phases in the value-chain: forecast production, forecast translation and integration, and climate information communication and adoption in decision-making (Section 3.1). The key findings from the study show that the nature of collaboration among the actors operating in each phase is a key determinant of the efficiency of the CS model and the usability of the communicated climate information.

Forecasts, agrometeorological services, and early warnings are the three main types of climate information communicated through CS. The five timescale forecasts widely used in CS for communication of information on climate risk warning and risk response advisory services are: (1) Weather forecasts (daily to weekly), (2) Seasonal forecasts (on a timescale of 1-6 months), (3) Short-term forecasts (1-5 years), (4) Intra-decadal/Medium-term forecasts (5-10 years), and (5) Decadal forecasts. Agrometeorological services communicated via the CS are comprised mostly of advisory information on the scheduling of planting operations, weeding, fertilizer applications, and climate-smart agriculture practices. The third type of climate information provided through CS is early warnings. The early warning system uses an integrated communication system to help farmers and decision-makers prepare for climate risks. Common climate risks event managed by early warning interventions includes drought, flood, and wildfires.

Reflecting on insights from the review of the various timescale forecasts used in CS deployment, two contemporary realities are observed to drive the high demand for shorter timescale forecasts in the African agriculture sector:

1. Most decision-making in the agriculture sector, such as the scheduling of planting or harvest operations that could benefit from integrated and targeted climate forecasts, is made at a range of temporal and spatial scales that are matching with a shorterterm forecast timeline. Not surprisingly, several authors $[11,15,60,66]$ reported that farmers are more interested in weather and seasonal forecasts. This is in contrast to CS' demand in the forest sector, where the majority of foresters are interested in longer timescale forecasts, due mostly to the fact that product harvesting is usually on a long timescale range of 8-30 years.

2. Another factor is the socio-economic profile of the farmers. The majority of farmers in the agriculture sector in the African countries are subsistence farmers, with poor and limited capacity for long-term planning. Hence, the timescale of their management decisions is often based on a short timescale. Consequently, the farmer mostly demands forecasts of shorter timescale horizons (weather and seasonal). This demand/supply factor plays a crucial role in tilting CS providers to mostly focus on providing forecasts for short timescales. Nevertheless, there is a gradual increase in the demand for forecasts of a longer timeline horizon.

The dominant use of forecasts of a shorter timescale in CS is also an indication of a dearth of effort towards long-term anticipatory adaptation actions in most African countries agriculture sectors. This may pose an unforeseen challenge to the sustainability of the agriculture sector. Without a considerable effort to understand what the future scenario and outlook will be for the African agriculture sector in the face of a changing climate, it may be that the government is unknowingly setting up the sector for a massive failure. There is a need for enhanced capacity towards being able to anticipate, predict the future scenario of the agriculture sector in the face of climate change across the scale from national to local so that appropriate anticipatory adaptation action can be devised and implemented.

The review of the extent to which CS facilitates indigenous knowledge systems' integration in climate information communication revealed that indigenous knowledge system integration is not yet an issue of significant emphasis in CS adoption in the African agriculture sector. Nonetheless, indigenous knowledge systems are not entirely neglected in the current model of CS deployment. Little of the reviewed literature reported the inclusion of indigenous knowledge holders in the process of forecasts translation into relevant climate information for actors in the agriculture sector. 
CS facilitates two-way learning (bottom-up and top-down) about climate-smart agricultural practices through the adoption of a participatory process in the generation and communication of climate information. This collaborative process is primarily through workshops and participatory scenario planning meetings. This ultimately influences learning and revisiting to ensure the relevancy, suitability, and usability of information disseminated via the CS.

Though CS usage has improved the communication and use of climate information in the African agricultural sector, the study findings have shed light on research gaps and opportunities that should be explored to maximize the benefit of CS application in the African agriculture sector. These are summarized as follow:

1. The most commonly used forecasts in the African agricultural sector are short-term, seasonal, and weather forecasts. Intra-decadal and decadal forecasts are sparingly used in agricultural risk management. This is a worrying trend because intra-decadal and decadal forecasts are useful for making strategic decisions and anticipatory adaptation plans. In order, therefore, to shift away from reactionary adaptation actions, the study recommends a further investigation on appropriate modalities for facilitating the integration of intra-decadal and decadal forecasts in climate information communication and usage in the African agricultural sector.

2. The poor integration of indigenous knowledge systems in CS adoption is a concern that warrants an increased emphasis on knowledge systems integration in CS deployment. This can be adopted as a strategy for facilitating CS acceptance, especially at the local scale. To this end, the study recommends further research on modalities of aligning scientific climate risk response strategies with farmers' sociocultural farming/coping practices.

3. Participatory process (e.g., workshop and participatory scenario planning) is increasingly used in CS adoption for facilitating forecast translation into relevant climate information and promoting two-way learning on climate risk and risk response strategy. To this end, several methods for reaching smallholder farmers (e.g., mobile phone) have been attempted by various agencies, but a scalable solution has yet to be found. Mobile phone usage in rural Africa is faced with challenges that impact its efficiency. The study, therefore, recommends a further investigation on appropriate modalities for facilitating impactful and sustainable reciprocated relationships among the actors along the CS value chain, with a specific focus on modalities for enhancing the efficiency of mobile phone usage in climate information communication in rural Africa.

4. The particular time-scale at which management decisions are made and the available forecast timescale greatly influences the integration of climate information in management action in the agriculture sector.

Author Contributions: M.N. developed the idea and received funding for the project. Both authors further developed the idea, permofrmed the analysis and wrote the manuscript. All authors have read and agreed to the published version of the manuscript.

Funding: This research was funded by the International Development Research Centre, Canada (IDRC) and Dept. for International Development, United Kingdom (DFID) through the ASSAR project (Adaptation at Scale in the Semi-Arid Region), [ACDI-ASSAR-1034].

Institutional Review Board Statement: This study was approved by the Ethics Research Committee of the faculty of Science, University of Cape Town, South Africa.

Informed Consent Statement: Not applicable.

Data Availability Statement: The data that support the findings of this study are available from the corresponding author upon reasonable request. 


\begin{abstract}
Acknowledgments: This research was funded by the Adaptation at Scales in Semi-Arid Regions (ASSAR) project. ASSAR project received funding from the International Development Research Centre, Canada (IDRC) and Dept. for International Development, United Kingdom (DFID). We would also like to thank all those who provided feedback on the scope of the review question, including the peer reviewers of a draft version of this document.
\end{abstract}

Conflicts of Interest: The authors declare no conflict of interest.

\title{
References
}

1. Milder, J.C.; Hart, A.K.; Dobie, P.; Minai, J.; Zaleski, C. Integrated landscape initiatives for african agriculture, development, and conservation: A region-wide assessment. World Dev. 2013, 54, 68-80. [CrossRef]

2. Roncoli, C.; Jost, C.; Kirshen, P.; Sanon, M.; Ingram, K.T.; Woodin, M.; Somé, L.; Ouattara, F.; Sanfo, B.J.; Sia, C.; et al. From accessing to assessing forecasts: An end-to-end study of participatory climate forecast dissem-ination in Burkina Faso (West Africa). Clim. Chang. 2009, 92, 433-460. [CrossRef]

3. Cadger, K.; Quaicoo, A.K.; Dawoe, E.; Isaac, M.E. Development interventions and agriculture adaptation: A social network analysis of farmer knowledge transfer in ghana. Agriculture 2016, 6, 32. [CrossRef]

4. Cooper, P.J.M.; Dimes, J.; Rao, K.P.C.; Shapiro, B.; Shiferaw, B.; Twomlow, S. Coping better with current climatic variability in the rain-fed farming systems of sub-Saharan Africa: An essential first step in adapting to future climate change? Agric. Ecosyst. Environ. 2008, 126, 24-35. [CrossRef]

5. Dayamba, D.S.; Ky-Dembele, C.; Bayala, J.; Dorward, P.; Clarkson, G.; Sanogo, D.; Mamadou, L.D.; Traoré, I.; Diakité, A.; Nenkam, A.; et al. Assessment of the use of Participatory Integrated Climate Services for Agriculture (PICSA) approach by farmers to manage climate risk in Mali and Senegal. Clim. Serv. 2018, 12, 27-35. [CrossRef]

6. Sivakumar, M.V.K.; Motha, R.P. Managing Weather and Climate Risks in Agriculture Summary and Recommendations. In Managing Weather and Climate Risks in Agriculture; Sivakumar, M.V.K., Motha, R.P., Eds.; Springer: Berlin, Heidelberg, 2007.

7. Vaughan, C.; Dessai, S. Climate services for society: Origins, institutional arrangements, and design elements for an evaluation framework. WIREs Clim. Chang. 2014, 5, 587-603. [CrossRef]

8. Machingura, F.; Nyamwanza, A.; Hulme, D.; Stewart, E. Climate information services, integrated knowledge systems and the 2030 Agenda for Sustainable Development. Sustain. Earth 2018, 1, 1. [CrossRef]

9. Tall, A.; Coulibaly, J.Y.; Diop, M. Do climate services make a difference? A review of evaluation methodologies and practices to assess the value of climate information services for farmers: Implications for Africa. Clim. Serv. 2018, 11, 1-12. [CrossRef]

10. Dougill, V.K.; Dixon, A.J.; Stringer, J.L.; Cull, T.L.C. Identifying climate services needs for national planning: Insights from Malawi. Clim. Policy 2017, 17, 189-202. [CrossRef]

11. Tall, A.; Jay, A.; Hansen, J. Scaling Up Climate Services for Farmers in Africa and South Asia Workshop Report; CCAFS Working Paper no. 40; CGIAR Research Program on Climate Change, Agriculture and Food Security (CCAFS): Copenhagen, Denmark, 2013; Available online: https://cgspace.cgiar.org/bitstream/handle/10568/27833/WP40.pdf?sequence=1\&isAllowed=y (accessed on 5 December 2018).

12. Ogallo, L. Integrating Indigenous Knowledge in Climate Risk Management to Support Community-Based Adaptation; Final Technical Report; The International Development Research Centre (IDRC): Ottawa, ON, Canada, 2010.

13. Ongoma, V.; Shilenje, Z.W. The effectiveness of agrometeorological information in the realization of Kenya's Vision 2030; lessons learnt from China. Ital. J. Agrometeorol. 2016, 1, 67-72.

14. Washington, R.; Harrison, M.; Conway, D. African Climate Report-A Report Commissioned by the UK Government to Review African Climate Science, Policy, and Options for Action; Department for Environment, Food and Rural Affairs: London, UK, 2004 ; p. 45.

15. Thornton, P.K.; Kristjanson, P.; Förch, W.; Barahona, C.; Cramer, L.; Pradhan, S. Is agricultural adaptation to global change in lower-income countries on track to meet the future food production challenge? Glob. Environ. Chang. 2018, 52, 37-48. [CrossRef]

16. Kadi, M.; Njau, L.N.; Mwikya, J.; Kamga, A. The State of Climate Information Services for Agriculture and Food Security in East African Countries; Working Paper No. 5; Climate Change, Agriculture and Food Security (CCAFS): Copenhagen, Denmark, 2011; Available online: www.ccafs.cgiar.org (accessed on 9 December 2018).

17. Bernard, M. Understanding user needs for climate services in agriculture. WMO Bull. 2011, 60, 67-72.

18. Dorward, P.; Clarkson, G.; Stern, R. Participatory Integrated Climate Services for Agriculture (PICSA): Field Manual; Walker Institute, University of Reading: Reading, UK, 2015; ISBN 9780704915633.

19. Street, R.; Buontempo, C.C.; Mysiak, J.; Karali, E.; Pulquério, M.; Murray, V.; Swart, R. How could climate services support disaster risk reduction in the 21st century. Int. J. Disaster. Risk Reduct. 2010, 34, 28-33. [CrossRef]

20. Wanders, N.; Wood, E.F. Assessing seasonal climate forecasts over africa to support decision-making. World Sci. Ser. Asia-Pac. Weather Clim. 2017, 10, 1-15. [CrossRef]

21. Kettle, N.P.; Dow, K.; Tuler, S.; Webler, T.; Whitehead, J.; Miller, K. Integrating scientific and local knowledge to inform risk-based management approaches for climate adaptation. Clim. Risk Manag. 2014, 4-5, 17-31. [CrossRef]

22. Qasim, M. Sustainability and wellbeing: A scientometric and bibliometric review of the literature. J. Econ. Surv. 2017, 31, 1035-1061. [CrossRef] 
23. Venkatasubramanian, K.; Tall, A.; Hansen, J.; Aggarwal, P.K. Assessment of India's Integrated Agrometeorological Advisory Service Program from a Farmer Perspective; CCAFS Working Paper no. 54; CGIAR Research Program on Climate Change, Agriculture and Food Security (CCAFS): Copenhagen, Denmark, 2014. Available online: https://assets.publishing.service.gov.uk/media/57a089 baed915d622c000385/CCAFS_WP_54.pdf (accessed on 7 January 2019).

24. Strauss, A.; Corbin, J. Basics of Qualitative Research: Grounded Theory Procedures and Techniques/Anselm Strauss, Juliet Corbin; Sage Publications: Newbury Park, CA, USA, 1990.

25. Charmez, K. Grounded theory methods in social justice research. In The SAGE Handbook of Qualitative Research, 4th ed.; Denzin, N., Lincoln, Y., Eds.; Sage: Thousand Oaks, CA, USA, 2011; pp. 359-380.

26. Haig, B.D. Précis of 'an abductive theory of scientific method'. J. Clin. Psychol. 2008, 64, 1019-1022. [CrossRef]

27. Ofoegbu, C.; New, M.G.; Staline, K. The effect of inter-organizational collaboration networks on climate knowledge flows and communication to pastoralists in Kenya. Sustainability 2018, 10, 4180. [CrossRef]

28. Coulibaly, Y.J.; Kundhlande, G.; Amosi, N.; Tall, A.; Kaur, H.; Hansen, J. What Climate Services Do Farmers and Pas-Toralists Need in Tanzania? Baseline Study for the GFCS Adaptation Program in Africa; CCAFS Working Paper no. 110; CGIAR Research Program on Climate Change, Agriculture and Food Security (CCAFS): Copenhagen, Denmark, 2015; Volume 112.

29. Kirui, C.; Oseni, S.V.; Bebe, O.B. Characterizing Access to Climate Information and Services by the Vulnerable Groups in Semi-arid Kenya. In Proceedings of the Third RUFORUM Biennial Meeting, Entebbe, Uganda, 24-28 September 2012; pp. $2077-2082$.

30. Nyamwanza, A.M.; New, M.; Fujisawa, M.; Johnston, P.; Hajat, A. Contributions of decadal climate information in agriculture and food systems in east and southern Africa. Clim. Chang. 2017, 143, 115-128. [CrossRef]

31. Hansen, J.W.; Mason, S.J.; Sun, L.; Tall, A. Review of seasonal climate forecasting for agriculture in Sub-Saharan Africa. Exp. Agric. 2011, 47, 205-240. [CrossRef]

32. Ziervogel, G.; Zermoglio, F. Climate change scenarios and the development of adaptation strategies in Africa: Challenges and opportunities. Clim. Res. 2009, 40, 133-146. [CrossRef]

33. Vermeulen, S.J.; Aggarwala, P.K.; Ainslie, A.; Angelone, C.; Campbell, B.M.; Challinor, A.J.; Hansen, J.W.; Ingram, J.S.I.; Jarvis, A.; Kristjanson, P.; et al. Options for support to agriculture and food se-curity under climate change. Environ. Sci. Policy 2012, 15, 136-144. [CrossRef]

34. Weichselgartner, J.; Kasperson, R. Barriers in the science-policy-practice interface: Toward a knowledge-action-system in global environmental change research. Glob. Environ. Chang. 2010, 20, 266-277. [CrossRef]

35. Waiswa, M.; Mulamba, P.; Isabirye, P. Climate information for food security: Responding to user's climate information needs. In Climate Prediction and Agriculture: Advances and Challenge; Sivakumar, M.V.K., Hansen, J., Eds.; Springer: Berlin/Heidelberg, Germany, 2007; pp. 225-248.

36. Tarchiani, V.; Camacho, J.; Coulibaly, H.; Rossi, F.; Stefanski, R. Agrometeorological services for smallholder farmers in West Africa. Adv. Sci. Res. 2018, 15, 15-20. [CrossRef]

37. Roudier, P.; Muller, B.; D'Aquino, P.; Roncoli, C.; Soumaré, M.; Batté, L.; Sultan, B. The role of climate forecasts in smallholder agriculture: Lessons from participatory research in two communities in Senegal. Clim. Risk Manag. 2014, 2, 42-55. [CrossRef]

38. Ziervogel, G.; Johnston, P.; Matthew, M.; Mukheibir, P. Using climate information for supporting climate change adaptation in water resource management in South Africa. Clim. Chang. 2009, 103, 537-554. [CrossRef]

39. Risbey, J.; Kandlikar, M.; Dowlatabadi, H. Scale, context, and decision-making in agricultural adaptation to climate variability and change. Mitig. Adapt. Strateg. Glob. Chang. 1994, 4, 137-165. [CrossRef]

40. Singh, C.; Daron, J.; Bazaz, A.; Ziervogel, G.; Spear, D.; Krishnaswamy, J.; Zaroug, M.; Kituyi, E. The utility of weather and climate information for adaptation decision-making: Current uses and future prospects in Africa and India. Clim. Dev. 2018, 10, 389-405. [CrossRef]

41. Ouédraogo, M.; Barry, S.; Zougmoré, R.B.; Partey, S.T.; Somé, L.; Baki, G. Farmers' willingness to pay for climate information services: Evidence from cowpea and sesame producers in Northern Burkina Faso. Sustainability 2018, 10, 611. [CrossRef]

42. Cornell, S.; Berkhout, F.; Tuinstra, W.; Tàbara, J.D.; Jäger, J.; Chabay, I.; de Wit, B.; Langlais, R.; Mills, D.; Moll, P.; et al. Opening up knowledge systems for better responses to global environmental change. Environ. Sci. Policy 2013, 28, 60-70. [CrossRef]

43. Stone, R.C.; Meinke, H. Weather, climate, and farmers: An overview. Meteor. Appl. 2006, 3 (Suppl. 1), 7-20. [CrossRef]

44. Oladele, O. Agricultural extension and rural advisory services: Proactiveness or reactiveness on climate change for food security in Africa. Life Sci. J. 2013, 10, 593-597.

45. Ouedraogo, I.; Diouf, N.S.; Ouédraogo, M.; Ndiaye, O.; Zougmoré, R.B. Closing the gap between climate information producers and users: Assessment of needs and uptake in Senegal. Climate 2018, 6, 13. [CrossRef]

46. Zongo, B.; Diarra, A.; Barbier, B.; Zorom, M.; Yacouba, H.; Dogot, T. Farmers' perception and willingness to pay for climate information in Burkina Faso. J. Agric. Sci. 2016, 8, 175-187. [CrossRef]

47. Brasseur, G.P.; Gallardo, L. Climate services: Lessons learned and future prospects. Earth's Future 2016, 4, 79-89. [CrossRef]

48. Nesheim, I.; Barkved, L.J.; Bharti, N. What is the role of agro-met information services in farmer decision-making? Uptake and decision-making context among farmers within three case study villages in Maharashtra, India. Agriculture 2017, 7, 70. [CrossRef]

49. Kniveton, D.; Visman, E.; Tall, A.; Diop, M.; Ewbank, R.; Njoroge, E.; Pearson, L. Dealing with uncertainty: Inte-grating local and scientific knowledge of the climate and weather. Disasters 2014, 39, S35-S53. [CrossRef]

50. Jones, L.; Harvey, B.; Godfrey-Wood, R. The Changing Role of NGOs in Supporting Climate Services; BRACED Resilience Intel, 4; London Overseas Development Institute: London, UK, 2016. 
51. Nyamwanza, A.M.; New, M. Anticipatory adaptation and the role of decadal climate information in rural African livelihood systems: Lessons from the Mid-Zambezi Valley, Zimbabwe. Int. J. Clim. Change Strateg. Manag. 2015, 8, 236-252. [CrossRef]

52. Cramer, L. Evaluation of Climate Services Interventions in the GFCS Adaptation Programme for Africa. Part II: Bene-ficiary Assessment Final Evaluation Summary Report. Statistics for Sustainable Development and Cramer-Njihia Consultants for the World Food Programme and CGIAR Research Program on Climate Change, Agriculture and Food Security (CCAFS). 2017. Available online: https:/ / gfcs.wmo.int/sites/default/files/projects/Global\%20Framework\%20for\%20Climate\%20Services $\% 20$ Adaptation $\%$ 20Programme \%20in \%20Africa \%20\%28GFCS\%20APA \%29\%2C\%20Phase \%20I\%2C\%20-\%20Building \%20Resilience \%20in \%20 Disaster\%20Risk\%20Management\%2C\%20Food\%20Security\%20and\%20Health/Final-report_1-Nov-2017-min.pdf (accessed on 6 January 2019).

53. Nadine, A.; Fanny, H.; Ousmane, N.; Armando, M.; Carlos, M.; Guy, F. Climate smart services: Case studies in Senegal, Burkina and Colombia. In Climate Smart Agriculture-Global Science Conference; CIRAD: Montpeiller, France, 2015; p. 113. Available online: http:/ / csa2015.cirad.fr/var/csa2015/storage/fckeditor/file/L3\%20Towards\%20Climate-smart\%20Solutions(1).pdf (accessed on 18 December 2018).

54. Mwaniki, F.; Gichuki, C.; Mwangi, M.; Mburia, P.; Wandago, B.O. Addressing challenges in communicating adaptation practices to smallholder farmers in Kenya through a radio intervention. J. Agric. Environ. Int. Dev. 2017, 111, 279-322. [CrossRef]

55. Kruk, M.C.; Parker, B.; Marra, J.J.; Werner, K.; Heim, R. Engaging with users of climate information and the copro-duction of knowledge. Weather Clim. Soc. 2017, 9, 839-849. [CrossRef]

56. Aker, J.C. Dial "A" for agriculture: A review of information and communication technologies for agricultural extension in developing countries. Agric. Econ. 2011, 42, 631-647. [CrossRef]

57. Kanno, H.; Sakurai, T.; Shinjo, H.; Miyazaki, H.; Ishimoto, Y.; Saeki, T.; Umetsu, C.; Sokotela, S.; Chiboola, M. Indigenous climate information and modern meteorological records in Sinazongwe district, Southern Province, Zambia. Jpn. Agric. Res. Q. 2013, 47, 191-201. [CrossRef]

58. Makondo, C.C.; Thomas, D.S.G. Climate change adaptation: Linking indigenous knowledge with western science for effective adaptation. Environ. Sci. Policy 2018, 88, 83-91. [CrossRef]

59. Buizer, J.; Jacobs, K.; Cash, D. Making short-term climate forecasts useful: Linking science and action. Proc. Natl. Acad. Sci. USA 2016, 113, 4597-4602. [CrossRef] [PubMed]

60. Best, A.; Holmes, B. Systems thinking, knowledge and action: Towards better models and methods. Evid. Policy J. Res. Debate Pract. 2010, 6, 145-159. [CrossRef]

61. Naaba, F.Z.; Abubakari, Z.; Ahmed, A. The role of climate services in agricultural productivity in Ghana: The per-spectives of farmers and institutions. Clim. Serv. 2019, 13, 24-32. [CrossRef]

62. Kalafatis, S.E.; Lemos, M.C.; Lo, Y.-J.; Frank, K.A. Increasing information usability for climate adaptation: The role of knowledge networks and communities of practice. Glob. Environ. Chang. 2015, 32, 30-39. [CrossRef]

63. Never, B. Regional Power Shifts and Climate Knowledge Systems: South Africa as a Climate Power? Working Paper No. 125; German Institute of Global and Area Studies: Hamburg, Germany, 2010; p. 311.

64. Sivakumar, M. Climate prediction and agriculture: Current status and future challenges. Clim. Res. 2006, 33, 3-17. [CrossRef]

65. Rasmussen, L.V.; Mertz, O.; Rasmussen, K.; Nieto, H. Improving how meteorological information is used by pastoralists through adequate communication tools. J. Arid. Environ. 2015, 121, 52-58. [CrossRef]

66. Mittal, S.; Hariharan, V.K. Mobile-based climate services impact on farmers risk management ability in India. Clim. Risk Manag. 2018, 22, 42-51. [CrossRef] 